\title{
RESPONSE OF DRACAENA PLANTS (DRACAENA FRAGRANS VAR. MASSANGEANA) TO SOME BIOFERTILIZERS
}

\author{
ZAKY, AMAL A. and BOSHRA A. EL-SAYED \\ Ornamental Plants Res. and Landscape Dep., Hort. Res. Inst., ARC, Giza, Egypt.
}

(Manuscript received 8 July 2012)

\begin{abstract}
This experiment was performed in the greenhouse at the nursery of Ornamental Plants Res. and Landscape Dep., Hort. Res. Inst., ARC., Giza, Egypt through two successive seasons (2009 and 2010 aiming to find out the response of Dracaena fragrans 'Massangeana' to biofertilizers. The obtained results revealed that biofertilization treatments significantly stimulated most of the studied characters compared to control. The treatment of Dracaena with Biogien (5and $10 \mathrm{~g} \mathrm{pot}^{-1}$ ) followed by Rhizobacterien (5and10g pot $^{-1}$ ) gave rise to the utmost high values of vegetative growth parameters [plant height $(\mathrm{cm})$, stem diameter $(\mathrm{cm})$, leaves blade area $\left(\mathrm{cm}^{2}\right)$, number of leaves plant ${ }^{-1}$, fresh and dry weights of leaves plant ${ }^{-1}(\mathrm{~g})$ ] as well as root length, number, fresh and dry weights. The treatment of Biogien followed by Rhizobacterien markedly improved chlorophyll a, b and carotenoids and gave the highest total carbohydrates $\%$ in leaves. Likewise, all fertilization treatments greatly raised the percentage of $\mathrm{N}, \mathrm{P}$ and $\mathrm{K}$ in the leaves, as reached the maximum by Biogien $\left(10 \mathrm{~g} \mathrm{pot}^{-1}\right)$. The addition of Biogien $\left(10 \mathrm{~g} \mathrm{pot}^{-1}\right)$ was the best treatment for all studied parameters of Dracaena plant. In general, the dominance in all previous measurements was for Biogien followed by Rhizobacterien which gave the highest values in most cases.

Key words: Dracaena, Biogien , Rhizobacterien , Microbien.
\end{abstract}

\section{INTRODUCTION}

The very popular Dracaena fragrans 'Massangeana'(Cornstalk Dracaena) belongs to Asparagaceae family, it is native to tropical Africa, from Sudan South to Mozambique, West to Côte d'Ivoir and Southwest to Angola, growing in upland regions at $600-2,250 \mathrm{~m}(2,000-7,380 \mathrm{ft})$ altitude. It is a slow growing shrub, usually multistemmed at the base, mature specimens reaching $15 \mathrm{~m}(49 \mathrm{ft})$ or more tall with a narrow crown of usually slender erect branches. Stems may reach up to $30 \mathrm{~cm}$ (12 in.) diameter on old plants, in forest habitats they may become horizontal with erect side branches. The leaves are glossy green, lanceolate, 20-150 cm (7.9-59 in) long and 2-12 cm (0.79-4.7 in) wide. The 'Massangeana variety is the most popular, due to its dramatic bright yellow central stripe on the leaves. In Africa, cornstalk Dracaena is widely grown as a hedge plant, it is suited to frost-free climates, in USDA zones 10-11. Elsewhere, it is primarily popular as a houseplant, valued for its tolerance of a wide range of indoor conditions from full sun to low light conditions. 
The temperature requirements for fragrans is a comfortable 75 degrees also, it does well in low light conditions. The water requirements are low. It is also very tolerant to neglect, and has been shown by the NASA Clean Air Study to help remove indoor pollutants such as formaldehyde, xylene and toluene (Huxley, 1992 and Wolverton, 1996).

Biofertilizers are from paramount importance for their beneficial effects on the physical, chemical and biological properties of soil organic matter, cation exchange capacity, availability of mineral nutrients to plant to increase productivity. This is attained through increasing the soil water holding capacity, promoting soil structure and enhancing the metabolic activity of micro organisms. Moreover, they can increase plant growth and quality of most plant species by enhancing water absorption and uptake of nutrients: e.g. phosphorus, potassium and nitrogen as well as $\mathrm{Zn}, \mathrm{Cu}, \mathrm{S}, \mathrm{B}$ and Mo (Dorer and Peacock, 1997).

The goal of this research work was to use natural safety environmental materials (Biogien, Rhizobacterien and Microbien) for their beneficial effects on plant growth and avoid the harmful effects caused by chemical fertilizers through decreasing its the use and costs requirements for Dracaena fragrans 'Massangeana' plant.

\section{MATERIALS AND METHODS}

This study was carried out at the Experimental Greenhouse (saran) of the Ornamental Plants Res. and Landscape Dep., Horticultural Research Institute, Agricultural Research Center, Giza, Egypt for two successive seasons (2009 and 2010). Dracaena fragrans 'Massangeana' plants were purchased from a commercial farm with average height of 10-12 cm and 2-3 leaves. On January1st 2009 and 2010, the plants were individually planted in $25 \mathrm{~cm}$ plastic pots filled with a mixture of clay: sand: peat $(1: 1: 1, \mathrm{v} / \mathrm{v} / \mathrm{v})$. Physical and chemical analysis of the used soil is presented in Tables (a) and (b). Plants were treated as follows during the growth season:

1- Control.

2- Biofertilizers containing effective micro organisms [Microbien (a commercial product contains a specific strain of Azotobacter, Azosprillam, Pasudomonus and BMogatherium), Rhizobacterien (a commercial product contains a specific strain of Rhizobium sp. bacteria, conc. $10^{7}-10^{9}$ cells $/ \mathrm{ml}$ ) and Biogien (a commercial product contains a specific clone of Azotobacter chroococcum bacteria, conc. $10^{6}$ cells $\left./ \mathrm{ml}\right]$ at the rates of 5 and $10 \mathrm{~g} /$ pot for each were applied monthly a soil drench. 


\section{Measurements}

1- Vegetative growth characters:

- Plant height $(\mathrm{cm})$ -Stem diameter $(\mathrm{cm}) \quad$ - Number of leaves /plant

- Leaves blade area $\left(\mathrm{cm}^{2}\right) \quad$ - Fresh and dry weights of leaves/ plant $(\mathrm{g})$

2- Root characters:

- Root length $(\mathrm{cm}) . \quad$-Number of roots/plant $\quad$ - Fresh and dry weights of roots

3- Chemical composition:

- Chlorophyll a, b and carotenoids were determined in fresh leaves (mg/g f.W.) according to Saric et. al. (1967).

- Total carbohydrates (\%) in leaves was determined according to Herbert et. al., (1971).

- Nitrogen, phosphorus and potassium \% in leaves were determined according to Jackson (1973).

The layout of the experiment was completely randomized design containing 7 treatments. Each treatment was repeated three times, each replicate contained 6 plants i.e. 18 plants in each treatment.

\section{Statistical analysis}

All data were subjected to statistical analysis according to the procedure reported by Snedecor and Cochran (1982) and means were compared by New Less Significant Difference (L.S.D) test at the $5 \%$ level of probability in the two seasons.

Table a. Physical and chemical analysis of the used soil.

\begin{tabular}{|c|c|c|c|c|c|c|c|c|c|}
\hline \multirow{2}{*}{$\begin{array}{l}\text { Soil } \\
\text { type }\end{array}$} & \multirow{2}{*}{$\begin{array}{c}\text { Particle } \\
\text { size } \\
(\%)\end{array}$} & \multicolumn{2}{|c|}{ Cations (meq/l) } & \multicolumn{2}{|c|}{ Anions(meq)/I) } & \multirow[b]{2}{*}{$\mathbf{N}$} & \multirow[b]{2}{*}{$\begin{array}{l}425 \\
\text { ppm }\end{array}$} & \multirow[b]{2}{*}{$\begin{array}{c}\text { B.D } \\
\left(\mathrm{g} / \mathrm{cm}^{3}\right)\end{array}$} & \multirow[b]{2}{*}{$\begin{array}{c}1.25 \\
5\end{array}$} \\
\hline & & $\mathrm{Ca}^{++}$ & 10.00 & $\underset{3}{\mathrm{HCO}^{-}}$ & 1.30 & & & & \\
\hline Sandy & 51.39 & $\mathrm{Mg}^{++}$ & 8.02 & $\mathrm{SO}^{-4}$ & 0.30 & $\mathrm{P}$ & $38.0 \mathrm{ppm}$ & WHC (\%) & 46 \\
\hline Silty & 31.63 & $\mathrm{Na}^{+}$ & 1.00 & $\mathrm{Cl}^{-}$ & 0.45 & $\mathrm{~K}$ & 564 ppm & $\mathrm{pH}$ & 7.22 \\
\hline Clayey & 17.98 & $\mathrm{~K}^{+}$ & 0.25 & ------- & ------- & & ------- & E.C(ds $/ m)$ & 1.02 \\
\hline
\end{tabular}

Table b. Chemical analysis of the used peatmoss.

\begin{tabular}{|c|c|c|c|c|c|}
\hline Organic matter & $90-95 \%$ & Water relation capacity & $\begin{array}{c}60-75 \\
\%\end{array}$ & $\mathrm{~K}$ & $1.77 \%$ \\
\hline Ash & $5-10 \%$ & Salinity & $0.3 \mathrm{~g} / \mathrm{I}$ & $\mathrm{Fe}$ & $\begin{array}{c}421 \\
\mathrm{ppm}\end{array}$ \\
\hline Density (Vol.Dry) & $80-90 \mathrm{Mg} / \mathrm{l}$ & $\mathrm{N}$ & $1.09 \%$ & $\mathrm{Mn}$ & $27 \mathrm{ppm}$ \\
\hline pH value & 3.4 & $\mathrm{P}$ & $0.23 \%$ & $\mathrm{Zn}$ & $41 \mathrm{ppm}$ \\
\hline
\end{tabular}




\section{RESULTS AND DISCUSSION}

\section{I- Effect of biofertilizers on vegetative growth traits}

Data shown in Table (1) prove that different trends on the obtained values were detected due to applying the different biofertilizers levels on plant height, stem diameter and leaves parameters.

\section{Plant height and stem diameter}

Data in Table (1) clear that all treatments significantly increased plant height and stem diameter over control except for stem diameter as the differences were not reached to the level of significance in both seasons. Moreover, the highest values of plant height and stem diameter were found with plants treated with $10 \mathrm{~g}$ followed by 5 pot $^{-1}$ Biogien in both seasons. However, the second category was occupied by plants treated with $10 \mathrm{~g} \mathrm{pot}^{-1}$ Rhizobacterien in both seasons. Generally, the increment in biofertilizers level from $5 \mathrm{~g}$ to $10 \mathrm{~g} \mathrm{pot}^{-1}$ led to an increase in plant height and stem diameter in both seasons. These results are in harmony with those of Eliwa et. al. (2009) on Iris tingitana who stated that EM (5\%) improved plant height and stalk diameter. Likewise, Martin et. al. (2003) mentioned that height and trunk diameter of Quercus palustris and scarlet Oak ( $Q$. coccinea) seedlings colonized with ectomycorrhizae were better than those of uncolonized ones. Meanwhile, the increase in plant height due to microorganisms of biofertilizer can be attributed to the capability of those microorganisms to induce beneficial effects on plant growth by contributing hormones such as cytokinins and auxins (Bouton et al, 1985).

\section{Number of leaves and their fresh and dry weights}

Data concerning leaves number formed on plants as affected by biofertilizers are presented in Table (1). Generally, the different fertilization treatments caused an increment in number of leaves plant ${ }^{-1}$ in both experimental years (which ranged from 13.55 to 16.70 in $1^{\text {st }}$ season and 13.00 to 18.40 in $2^{\text {nd }}$ one) more than control (9.67and10.33 in both seasons, respectively). In this respect, the utmost high values in leaf formation was obtained in plants which received Biogien followed by Rhizobacterien in both seasons. Moreover, applying the lowest rate of biofertilizers showed also a favorable effect in this respect.

Regarding fresh and dry weights of leaves $(\mathrm{g})$ as affected by biofertilizers data are presented in Table (1). Generally all treatments significantly increased fresh and dry weights of leaves $(\mathrm{g}$ ) over control in both seasons. The heaviest fresh and dry weights of leaves were found in treated plants with Biogien followed by Rhizobacterien compared with the other treatments and the differences were significant in both 
seasons. The previous results are in parallel line with Abdel Fattah et. al. (2009) on Dracaena and Ruscus who found that $10 \mathrm{ml} / /$ biofertilizer significantly increased number of leaves and their fresh and dry weights.

\section{Blade area}

The data on blade area shown in Table (1) reveal that supplying plants with biofertilizers at the levels of 5 and $10 \mathrm{~g} \mathrm{pot}^{-1}$ led to increase blade area over that gained from the control in both seasons. Meanwhile, blade area was significantly increased comparing with that attained from the control or other biofertilizers by receiving plants the level of $10 \mathrm{~g} \mathrm{pot}^{-1}$. In this connection, the pronounced effect of fertilization resulted from $10 \mathrm{~g} \mathrm{pot}^{-1}$ Biogien followed by $10 \mathrm{~g}$ pot $^{-1}$ Rhizobacterien. These results are in harmony with those of Ahmed et. al. (2005) on Populous nigra and Sarhan et. al. (2007) on jojoba.

Table.1. Effect of some biofertilizers on some vegetative traits of Dracaena fragrans 'Massangeana' during two successive seasons (2009 \& 2010).

\begin{tabular}{|c|c|c|c|c|c|c|}
\hline \multicolumn{7}{|l|}{$1^{\text {st }}$ season } \\
\hline \multirow{2}{*}{ Treatments } & \multirow{2}{*}{$\begin{array}{c}\begin{array}{c}\text { Plant } \\
\text { height }\end{array} \\
\\
(\mathrm{cm})\end{array}$} & \multirow{2}{*}{$\begin{array}{c}\begin{array}{c}\text { Stem } \\
\text { diameter }\end{array} \\
\text { (cm) }\end{array}$} & \multicolumn{4}{|c|}{ Leaves } \\
\hline & & & $\begin{array}{l}\text { No. } \\
(\mathrm{cm})\end{array}$ & $\begin{array}{c}\text { Blade } \\
\text { area } \\
\left(\mathrm{cm}^{2}\right)\end{array}$ & $\begin{array}{l}\text { F.W. } \\
\text { (g) }\end{array}$ & $\begin{array}{l}\text { D.W. } \\
\text { (g) }\end{array}$ \\
\hline Control & 50.25 & 1.20 & 9.67 & 82.51 & 37.66 & 4.11 \\
\hline $5 \mathrm{~g}$ Microbien & 56.23 & \multirow{2}{*}{$\begin{array}{l}1.44 \\
1.52\end{array}$} & 13.55 & 94.90 & 42.71 & 5.16 \\
\hline $10 \mathrm{~g}$ Microbien & 60.32 & & 15.60 & 98.60 & 47.00 & 7.15 \\
\hline $5 \mathrm{~g}$ Rhizobacterien & 62.18 & 1.46 & 14.45 & 95.53 & 50.00 & 7.30 \\
\hline 10g Rhizobacterien & 68.30 & 1.70 & 14.85 & 98.88 & 55.00 & 9.08 \\
\hline $5 \mathrm{~g}$ Biogien & 73.63 & 1.75 & 15.81 & 100.0 & 62.77 & 12.56 \\
\hline 10g Biogien & 78.90 & 1.81 & 16.70 & 110.0 & 66.73 & 13.04 \\
\hline L.S.D. & 2.67 & 1.26 & 2.49 & 2.82 & 2.63 & 2.66 \\
\hline \multicolumn{7}{|l|}{$2^{\text {nd }}$ season } \\
\hline Control & 54.17 & 1.25 & 10.33 & 70.40 & 39.80 & 4.80 \\
\hline $5 \mathrm{~g}$ Microbien & 61.55 & 1.51 & 13.00 & 95.30 & 46.55 & 6.33 \\
\hline 10g Microbien & 65.61 & 1.72 & 14.65 & 110.0 & 50.20 & 7.35 \\
\hline $5 \mathrm{~g}$ Rhizobacterien & 69.25 & 1.65 & 14.89 & 96.46 & 54.67 & 8.05 \\
\hline 10g Rhizobacterien & 74.58 & 1.78 & 15.61 & 113.5 & 59.30 & 10.13 \\
\hline $5 \mathrm{~g}$ Biogien & 79.46 & 1.88 & 17.82 & 116.0 & 64.20 & 13.35 \\
\hline $10 \mathrm{~g}$ Biogien & 82.56 & 1.91 & 18.40 & 125.0 & 68.00 & 14.03 \\
\hline L.S.D. & 2.56 & 1.36 & 2.51 & 2.77 & 2.63 & 2.56 \\
\hline
\end{tabular}




\section{II- Effect of biofertilizers on root parameters}

Data in Table (2) clearly show that all treatments significantly increased root number, length and their fresh and dry weights over control in both seasons. Beneficial effects were scored on root number, length and their fresh and dry weights due to using the biostimulants treatment in both seasons, with the mastery of Biogien followed by Rhizobacterien treatments which gave the highest number, the tallest roots and the heaviest fresh and dry weights of roots than other treatments used in both seasons. On the same line El-Sayed and El-Feky (2007) declared that biogien at 10 plant $^{-1}$ improved vegetative and root growth of Ficus binnendijikii plants .Similar results were obtained by Abdel Fattah et. al. (2009) and Ahmed et. al. (2005).

In this respect, improving the vegetative and root growth may explain the role of biofertilizers which fix more atmospheric $\mathrm{N}$ and secrete more vitamins and growth promoting substances necessary for good and healthy growth.

Table 2. Effect of some biofertilizers on root traits of Dracaena fragrans 'Massangeana' during two successive seasons (2009 \& 2010).

\begin{tabular}{|c|c|c|c|c|}
\hline \multicolumn{5}{|l|}{$1^{\text {st }}$ season } \\
\hline \multirow[b]{2}{*}{ Treatments } & \multicolumn{4}{|c|}{ Roots } \\
\hline & $\begin{array}{l}\text { No. } \\
\text { (cm) }\end{array}$ & $\begin{array}{c}\text { Length } \\
\text { (cm) }\end{array}$ & $\begin{array}{c}\text { F.W. } \\
(\mathbf{g})\end{array}$ & $\begin{array}{c}\text { D.w. } \\
\text { (g) }\end{array}$ \\
\hline Control & 10.40 & 22.80 & 9.150 & 2.200 \\
\hline $5 \mathrm{~g}$ Microbien & 14.33 & 33.79 & 14.75 & 4.130 \\
\hline 10g Micrope & 16.27 & 35.70 & 15.60 & 5.067 \\
\hline $5 \mathrm{~g}$ Rhizobacterien & 16.67 & 38.20 & 16.55 & 6.100 \\
\hline 10g Rhizobacterien & 20.26 & 40.34 & 18.11 & 8.350 \\
\hline $5 \mathrm{~g}$ Biogien & 22.30 & 41.26 & 20.61 & 8.120 \\
\hline 10g Biogien & 25.34 & 44.67 & 21.80 & 8.250 \\
\hline $\begin{array}{ll}\text { L.S.D. } & 0.05 \\
\end{array}$ & 2.49 & 2.52 & 2.51 & 2.59 \\
\hline \multicolumn{5}{|l|}{$2^{\text {nd }}$ season } \\
\hline Control & 11.32 & 24.50 & 11.68 & 2.291 \\
\hline $5 \mathrm{~g}$ Microbien & 14.91 & 37.91 & 14.87 & 4.201 \\
\hline 10g Microbien & 17.50 & 39.85 & 16.21 & 5.360 \\
\hline $5 \mathrm{~g}$ Rhizobacterien & 18.09 & 38.81 & 17.23 & 5.820 \\
\hline 10g Rhizobacterien & 19.80 & 43.70 & 18.90 & 7.620 \\
\hline $5 g$ Biogien & 21.92 & 44.60 & 20.92 & 8.150 \\
\hline 10g Biogien & 25.22 & 48.20 & 22.09 & 8.750 \\
\hline L.S.D. & 2.58 & 2.53 & 2.54 & 2.54 \\
\hline
\end{tabular}




\section{III- Chemical composition as affected by biofertilizers}

Results of Table (3) show the increment in chlorophyll (a) and (b) accumulation in leaves associated with the different fertilizer treatments compared with the control in both seasons. However, the promotive action was more obvious with applying Biogien followed by Rhizobacterien treatments in the two seasons. However, a favorable influence was detected due to receiving the plants $10 \mathrm{~g} \mathrm{pot}^{-1}$ Biogien which reached the highest effect in the two seasons. The aforementioned findings are in harmony with those of Eliwa et. al. (2009) on Iris tingitana cv. Wedgewood. Regarding the effect on the carotenoids content, a clear increment in such constituents in leaves was detected with control treatment $(0.44$ and $0.46 \mathrm{mg} / \mathrm{g}$ f.w., respectively in both seasons). Meanwhile, supplying plants with Biogien as well as Rhizobacterien gave a contrary effect. Such treatments declined the values of the same constituents in the two seasons. In this connection, El- Khateeb et. al. (2010) found that the use of mycorrhizae on Calia secundiflora decreased the leaves content of carotenoids.

Regarding total carbohydrates \% in leaves, as shown in Table (3) plants treated with $10 \mathrm{~g} \mathrm{pot}^{-1}$ Biogien considerably increased total carbohydrates $\%$ in leaves over control and other treatments used (33.73and $36.80 \%$, respectively) in both seasons. Also, great influence was observed in the obtained values as a result of supplying the plants with $5 \mathrm{~g} \mathrm{pot}^{-1}$ Biogien ( 32.38 and $36.25 \%$, respectively) followed by $10 \mathrm{~g} \mathrm{pot}^{-1}$ Rhizobacterien treatment in both seasons. The other biofertilizers revealed also an increment but with less effect on total carbohydrates content. Referring to the increment in total carbohydrates content in leaves due to biofertilizers, El- Khateeb et. al. (2010) found that the use of Mycorrhizae on Calia secundiflora increase the leaves content of total carbohydrates.

As for the mineral analysis, data in Table (4) reveale a clear increment in nitrogen, phosphorus and potassium accumulation in leaves in response to the different fertilizer treatments so as to reach their maximum records with the treatment of $10 \mathrm{~g} \mathrm{pot}^{-1}$ Biogien in the two seasons. Meanwhile, control plants recorded the lowest values in this concern. In addition, supplying plants Rhizobacterien at $10 \mathrm{~g}$ pot $^{-1}$ proved its superiority in raising nitrogen accumulation in leaves in both seasons.

These results are supported by the obtained data of Dubey and Ginwal (1997) reported that Mycorrhizae increased the absorption area of the roots and provided host plants with nutrients. Mycorrhizae improve the uptake of nutrients. In addition, a biofertilizer as a preparation containing many races of beneficial bacteria that can fix atmospheric $\mathrm{N}$ and can release nutrients from rocks and organic matter in the soil to 
become available for plants (Quoreshi, 2003) on Picea mariana. On the same line, were those results attained by Attia and Abdel-Azeem (2005) on Lawsonia inermis.

Table. 3. Effect of some biofertilizers on total carbohydrates\% and photosynthetic pigments content in leaves of Dracaena fragrans 'Massangeana' during two successive seasons (2009 \& 1010).

\begin{tabular}{|c|c|c|c|c|c|c|c|c|}
\hline \multirow[t]{2}{*}{ Treatments } & \multicolumn{2}{|c|}{$\begin{array}{c}\text { Total carbohydrates } \\
\text { (\%) }\end{array}$} & \multicolumn{2}{|c|}{ Cl. a (mg/g f.w.) } & \multicolumn{2}{|c|}{ Cl. b (mg/g f. w.) } & \multicolumn{2}{|c|}{$\begin{array}{l}\text { Carotenoids } \\
\text { (mg/g f.w.) }\end{array}$} \\
\hline & 2009 & 2010 & 2009 & 2010 & 2009 & 2010 & 2009 & 2010 \\
\hline Control & 19.85 & 20.15 & 0.80 & 0.84 & 0.32 & 0.30 & 0.44 & 0.46 \\
\hline $5 \mathrm{~g}$ Microbien & 23.50 & 26.00 & 0.98 & 1.09 & 0.36 & 0.37 & 0.34 & 0.33 \\
\hline 10g Microbien & 24.80 & 28.13 & 1.08 & 1.12 & 0.39 & 0.41 & 0.38 & 0.39 \\
\hline $5 \mathrm{~g}$ Rhizobacterien & 28.25 & 31.40 & 1.16 & 1.18 & 0.41 & 0.43 & 0.35 & 0.36 \\
\hline 10g Rhizobacterien & 30.68 & 33.75 & 1.21 & 1.25 & 0.44 & 0.46 & 0.37 & 0.37 \\
\hline $5 \mathrm{~g}$ Biogien & 32.38 & 36.25 & 1.28 & 1.31 & 0.45 & 0.47 & 0.35 & 0.36 \\
\hline $10 \mathrm{~g}$ Biogien & 33.73 & 36.80 & 1.33 & 1.35 & 0.48 & 0.49 & 0.33 & 0.31 \\
\hline
\end{tabular}

Table. 4. Effect of some biofertilizers on $\mathrm{N}, \mathrm{P}$ and $\mathrm{K}(\%)$ in leaves of Dracaena fragrans 'Massangeana' during two successive seasons (2009 \&2010)

\begin{tabular}{|l|c|c|c|c|c|c|}
\hline \multirow{2}{*}{ Treatments } & \multicolumn{2}{|c|}{ Nitrogen } & \multicolumn{2}{c|}{ Phosphorus } & \multicolumn{2}{c|}{ Potassium } \\
\cline { 2 - 7 } & $\mathbf{2 0 0 9}$ & $\mathbf{2 0 1 0}$ & $\mathbf{2 0 0 9}$ & $\mathbf{2 0 1 0}$ & $\mathbf{2 0 0 9}$ & $\mathbf{2 0 1 0}$ \\
\hline Control & 1.21 & 1.19 & 0.31 & 0.27 & 1.65 & 1.72 \\
\hline $5 \mathrm{~g} \mathrm{Microbien}$ & 1.46 & 1.51 & 0.33 & 0.34 & 2.33 & 2.45 \\
\hline $10 \mathrm{~g}$ Microbien & 1.58 & 1.63 & 0.35 & 0.35 & 2.57 & 2.51 \\
\hline $5 \mathrm{~g}$ Rhizobacterien & 1.60 & 1.71 & 0.35 & 0.36 & 2.63 & 2.61 \\
\hline $10 \mathrm{~g}$ Rhizobacterien & 1.69 & 1.77 & 0.36 & 0.36 & 2.67 & 2.65 \\
\hline $5 \mathrm{~g}$ Biogien & 1.78 & 1.80 & 0.38 & 0.40 & 2.75 & 2.73 \\
\hline $10 \mathrm{~g}$ Biogien & 1.82 & 1.84 & 0.39 & 0.41 & 2.79 & 2.78 \\
\hline
\end{tabular}




\section{REFERENCES}

1. Abdel Fattah, G. H., $\quad$ B. A. El-Sayed and S. A. M. Khenizy. 2009. Response of Dracaena and Ruscus plants to humic acid and biofertilizer supply. Annals of Agric. Sc., Moshtohor, 47 (1):111-119.

2. Ahmed, A. A., F. A. Ahmed and F. D. Omar. 2005. Response of Populous nigra seedling to Azotobacter vinelandii transformation isolation and $\mathrm{N}$-fertilization. Proc. 6th Arab. Conf. Hort., March 20-22, Dept. Hort., Fac. Agric., Ismailia, Egypt: 91108.

3. Attia E. M. and H. H. M. Abdel-Azeem. 2005. Effect of biofertilization on yield and active materials in Lawsonia inermis L. plants. Proc. 6th Arab Conf. Hort., March 20-22, Dept. Hort., Fac. Agric., Ismailia, Egypt: 109-128.

4. Bouton, J. H., S.L. Albrecht and D. A. Zuberer. 1985. Screening and selection of pearl millet for root associated bacterial nitrogen fixation. Field Crops Res., 11:131-140.

5. Dorer, S. P. and C. H. Peacock. 1997. The effect of humate and organic fertilizer on establishment and nutrition of creeping bentgrass putting greens. Inter. Turfgrass Soci. Res. J., 8: 437- 443.

6. Dubey, R. C. and H.S. Ginwal. 1997. Prospects of Mycorrhizael fungi in the Himalaya Forms, Function and Management. Himalayan Microbial Diversity Part 2. Today and Tomorrow's Printers and Publ., New Delhi, p: 317-338.

7. El- Khateeb, M.A., A. A. Nasr, A.N. Fahmy and A.H.H. Dorgham. 2010. Effect of GA3 and growth biostimulants on growth and chemical composition of Calia secundiflora plants. Journal of Horticultural Science \& Ornamental Plants, 2(2): 118-124.

8. Eliwa, N.Y., B. B. Rezk Alla and M. A. El-Shamy. 2009. Effect of organic and biofertilizer treatments on growth, flowering, bulb production and chemical constituents of Iris tingitana cv. Wedgewood plants. J. Boil. Chem. Environ. Sci., 4(2): 441-461.

9. El-Sayed, B. A. and A. H. El-Feky. 2007. Effect of biofertilizers (Rhizobacterien, nitrobien and biogien) on growth of Ficus binnendijikii L. (Amstel King) plant. Egypt. J. Appl.sci., 22(10A):157-170.

10. Herbert, D., P.J. Philips and R.E. Strange. 1971. Determination of total carbohydrates. Methods in Microbiol., 58: 209-344.

11. Huxley, A., ed. 1992. New RHS Dictionary of Gardening 2: 96. Macmillan ISBN 0333-47494-5. 
12. Jackson, M.L. 1973. Soil Chemical Analysis. Prentice. Hall, New Delhi., p: 219221.

13. Martin, T. P., J. R. Horris, G. K. Eaton and O. K. Miller. 2003. The efficacy of ectomycorrhizal colonization of pine and scarlet oak in nursery production. J. Environ. Hort., 21(1): 45-50.

14. Quoreshi, A. M. 2003. Nutritional preconditioning and ectoMycorrhizael formation of Picea mariana (Mill) B.S.P. seedlings. Eurasian J. Forests Res., 6:1-63.

15. Sarhan, A. Z., E. I. El-Maadawy and S. S. Surour. 2007. Effect of biopromoters and biofertilizers application on growth and chemical composition of jojoba plants. J. Agric.Sci., Mansoura Univ., 32(8):6575-6598.

16. Saric, M., R. Kastrori, R. Curic, T. Cupina and I. Geric. 1967. Chlorophyll determination. Univ. Unoven Sadu Parktikum is fizologize Bibjoke, Beagard, Haunca, Anjiga, p215.

17. Snedecor, C.W. and W. G. Cochran. 1982. Statistical Methods. 7th ed. The Iowa State Univ. Press Ames. Iowa, USA.

18. Wolverton, B.C. 1996. How to Grow Fresh Air. New York: Penguin Books. 


\title{
إستجابة نبات دراسينا الذرة صنف 'Massangeana' لبعض الآسمدة الحيوية
}

\author{
أمال عبد الغفار زكى بشرة عبد الله السبد
}

قسم بحوث نباتات الزينة و تنسيق الحدائق - معهد بحوث البساتين - مركز البحوث الزراعية - الجيزة $\cdot$

أجريت تجربة أصص فى صوبة سيران بمشتل قسم بحوث نباتات الزينـة و تتسيق الحدائق -

معهد بحوث البساتين - مركز البحوث الزراعية- جيزة- مصر خلال موسمى 2009و 2010 لدراسة استجابة نبات دراسينا الذرة صنف 'Massangeana' للمعاملة بالأسمدة الحيوية وتأثيرذلك على الصفات المورفولوجية والمحتوى الكيماوى للنبات وقد أظهرت النتائج الأتى :

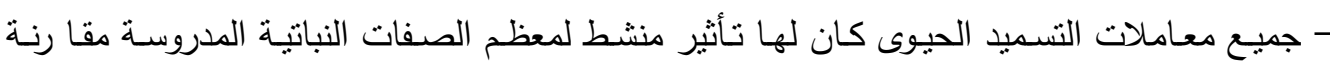

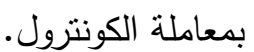
- حققت معاملة نبات الدراسينا بالبيوجين (5،10جم/أصبص) أو المعاملة بالريزوباكتبرين (5،10جم /أصبص) حققت أفضل النتائج بالنسبة للنمو الخضرى إرتفاع النبات (سم) ، قطر السـاق (سم) ،

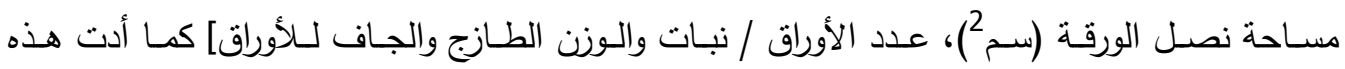

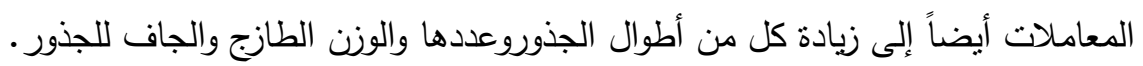
- المعاملة بالبيوجين ويليها المعاملة بالريزوباكتيرين حسنت بشكل واضح محتوى الأوراق من الكلوروفيل

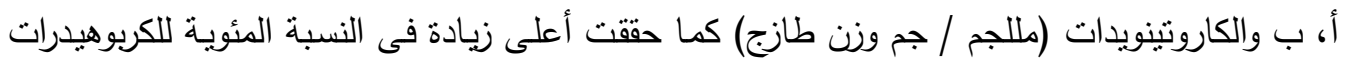
الكلية فى الاوراق. -أظهرت النتائج آن كل معاملات التسميد أدت إلى زيادة واضحة فى النسبة المئوية لكل من النتروجين والفسفور والبوتاسيوم فى الاوراق حيث بلغ أقصاه نتيجة للمعاملة بالبيوجين (10جم/ أصيص). - أثنارت النتائج إلى أن إضافة البيوجين (10 التم /أصيص) حققت أفضل النتائج فى جميع القياسات النباتية المدروسة لنبات الدراسينا. - بصـفة عامـة كانت السيادة في جميـع القياسـات السـابقة نتيجـة المعاملـة بـالبيوجين يلبهـا المعاملـة بالريزوباكتيرين والتى أعطت أعلى النتائج فى معظم الحالات. الكلمات الدالة : نبات الدراسينا - بيوجين - ريزوباكتيرين - ميكروبين. 